\title{
Formal Vacillation in Modern American Drama
}

By

Fredrik Chr. Brøgger

University of Tromsø

One of the most fascinating features of modern American drama is its constant vacillation between the different dramatic modes of realism, expressionism, and (more recently) absurdism, both within one and the same period and within the individual productions of major playwrights. No single mode can for instance be said to typify the plays by modern dramatists like O'Neill, Miller, Williams, or Albee. Using Albee's production as the most comprehensive illustration, this essay will attempt to look more closely at the thematic implications of this medley of dramatic modes and to speculate on some of the possible reasons for such a continual vacillation in dramatic form.

The basic presumption behind this essay is that the dramatic modes of realism, expressionism, and absurdism express quite different world views. This in itself is a problematic contention, not least since these modes are frequently combined in modern plays. Historically, however, these differences in world view can easily be illustrated when one considers for instance the development from the early realistic plays by Ibsen, through the late expressionist plays by Strindberg, to the absurdist plays by Beckett. In these instances we find, for example, differing conceptions of character, dialogue, plot, and the nature of dramatic representation itself, which together reflect quite divergent visions of life. In the subsequent discussion I will briefly summarize these differences in order to delineate the formal-historical context in relation to which especially Albee's production can be studied. 
The changes in the conception of character are among the most striking features of the development of modern drama. In Ibsen's plays, characterization serves not least to reveal the dialectic relationship between individual and social existence. Arthur Miller describes this feature of realism very well in his essay "The Shadows of the Gods" when he says that "society is inside of man and man is inside society, and you cannot even create a truthfully drawn psychological entity on the stage until you understand his social relations and their power to make him what he is and to prevent him from being what lie is not." 1 Characters in realist plays thus tend to be both individualized and typified. Although these two aspects of characterization need not receive the same emphasis from one realist play to another - we may for instance speak of social realism (prototypically The Pillars $₫$ Society) and psychological realism (prototypically Hedda Gabler) - the interplay between social and psychological factors will always be accentuated. The pasts of the main characters are often stressed as well (as in Ibsen's retrospective technique) and testify to the analytical perspective of realist drama: it does not only want to present life, but to explain it. The concern in realism with the complex logic of personal and social behavior also tends to make it emphasize the idea of identity, self-knowledge, and wholeness of character. In Strindberg's expressionist plays, however, character is regarded as something much less coherent and unified than in the realist tradition, something emotional rather than rational, something precariously fragmented and ambiguous. ${ }^{2}$ Already Strindberg's Preface to Miss Julie (1888) testifies to this change in the conception of character, perhaps most consistently realized in his play To Damascus: "My souls are conglomerations of past and present cultures, scraps from books and newspapers, bits and pieces of people, shreds torn from Sunday clothing that has turned into rags, just as the human soul is patched together."3 Finally, in absurdist plays the dissolution of character has been taken to an unprecedented extreme where people, existing in a void, disconnected from both history and society, have little "character" except in terms of the roles they may adopt in a given situation. Lacking identity, they are also static: there is nothing to develop from or into, hence nothing to explain and nothing to learn.

This dissolution of character has been accompanied by a gradual disintegration, or disfiguration, of both traditional dialogue and plot - of traditional dramatic form itself. Ibsen's dialogue for instance - especially in his plays of early social realism - has some- 
thing peculiarly orderly about it, at least to modern ears. At times - at its worst perhaps - it may resemble a debate, where each person gets his say. More importantly, though, this kind of dialogue reflects a central belief in argument and discourse, in the possibilities of human communication. In his Preface to Mis Julie, however, Strindberg heralds another conception of dialogue, one which "wanders, providing itself in the first scenes with material which is afterwards worked over, picked up, repeated, developed, expounded, like the theme in a musical composition."4 The dialogue has in a sense become internalized as well: it sometimes appears more like intensified mental exchanges than real-life conversation. Again, when we come to absurdist drama, there is a complete dissolution: the dialogue, full of stereotype phrases reflecting stereotype attitudes, never seems to get anywhere. In Beckett, for instance, the breakdown of communication is shown by the fact that the characters constantly talk past each other, or are unable to find the right words, or simply do not want to communicate, or become incoherent, or produce sheer nonsense. The theater of the absurd employs a dialogue of complete relativism which reflects, as Martin Esslin suggests, "the devaluation and disintegration of language."s

It is, however, the changes in the conception of plot that have had the most far-reaching consequences for the form of modern drama. Essentially realist drama conceives of plot as story, as epic development, the kind of plot which according to Aristotle represents "the soul" of drama, making events follow as cause and effect. Arthur Miller characterizes this epic progression of realist plays very well when he speaks of Ibsen's ability to "forge a play upon a factual bedrock. A situation in his plays is never stated but revealed in terms of hard actions, irrevocable deeds; and sentiment is never confused with the action it conceals."6 This emphasis on action helps define people as social beings and gives realist drama a "public" and "objective" dimension. In expressionist drama, however, the emphasis on subjective experience results in a very different conception of dramatic structure, as Strindberg's Preface to $\boldsymbol{A}$ Dream Play makes abundantly clear:

In this dream play, as in his former dream play To Damascus, the author has sought to imitate the disconnected but apparently logical form of a dream. Anything may happen, everything is possible and probable. Time and space do not exist; taking off from an insignificant base in real life, the imagination spins and weaves new patterns: a mixture of memories, experiences, free fancies, absurdities, and improvisations. 
The characters split, double, multiply, evaporate, condense, flow out, converge. But one consciousness stands above them all, that of the dreamer ...?

As Richard Gilman puts it (1974), "There are sentences in these two paragraphs ... which describe nearly the whole of what we think of as avant-garde drama of the past fifty or more years." 8 They certainly contain the key to many of the formal features of absurdism, but with one fundamental difference: Strindberg insists, after all, on the importance of a central, organizing consciousness. So, although plot loses its objective character as story, it is nonetheless crucial as a more privatized, highly deliberate symbolic structure. Thus dramatic structure becomes synchronic rather than diachronic, and transcendental rather than mimetic. In absurdist plays, however, we find a deliberate rejection even of this subjective creation of order. The senselessness of life, whether at the public or private level, is often revealed through what Martin Esslin calls "the deliberate omission of an explanation or a motivation for the action;" 9 the scenes appear like a series of frozen tableaux, seemingly at random, giving an impression of incoherence or stale repetitiveness.

These changes in plot reflect at the same time new conceptions of dramatic art itself. Realist plays aim at mimesis, at mirroring or reproducing everyday life, at creating the illusion of the fourth wall as if the audience is watching something that really happens before their eyes. In expressionist plays, however, ideas of verisimilitude are rejected in favor of an imaginative transformation of life. In Strindberg's dream plays, for instance, the stage sets reflect strangely dream-like landscapes, a world colored by a subjective state of mind. This symbolic projection of experience makes the illusion of the fourth wall vanish, and the play calls attention to itself as a work of art. Inherent in such a symbolic recreation of life is the idea that a subjective vision provides a more "genuine" reflection of reality than "mere" mimesis. Absurd drama, however, is neither quite mimetic or symbolic, since any vision of meaningful order is rejected. Absurdist plays can perhaps rather be said to be metaphorical: the characterization, dialogue, and "plot" of Waiting for Godot, for instance, are a metaphorical short-hand for the meaninglessness of life. Any remnant of a fourth wall is also frequently shattered by a playing around with dramatic convention: when characters address the audience or comment on being part of a play, the distinctions between the play-acting of life and the role-playing 
of the theater become blurred, which again serves to reflect the theme of absurdity.

Together, these different aspects of dramatic form reflect quite divergent world views, which already lie implicit in the preceding discussion. The concern in realist drama with the interplay between social and individual experience, and with the imitation of people in action, reflects a vision of a potential humanistic social order, inherited from Classical and Christian humanism, according to which ignorance is regarded as evil, and (self) knowledge as necessary for personal and social growth and liberation. Expressionism, on the other hand, marks the beginning of a disintegration of the essentially analytical, humanistic world view of 19th century realism: it implies a distrust of the public perspective, a disillusionment with rationalism, and a corresponding retreat toward an increasingly private vision of life. The picture of the breakdown of communal coherence is, however, in a sense compensated for by the search for a personal aesthetic order. This nevertheless reveals that man finds less and less to identify with in society; terms like alienation and estrangement become important to describe his predicament. This development in expressionist drama is taken to its logical dead end in the theater of the absurd: its vision of the total relativity and futility of human experience represents the final blow against bourgeois humanist liberalism.

In this bird's-eye view of literary history, the development of modern drama seems deceptively straightforward. So too with historical-sociological explanations of the evolution of these modes: the increasing privatization of art, including drama, can be viewed as the result of the development of an industrial, capitalist world, where the commercialization of humanist ideals and the reification of man's labor have produced an ever encreasing sense of social fragmentation and personal alienation. When we look beneath such general observations, however, we find that this neatly drawn map becomes highly problematic because it does not quite fit the landscape of modern drama. This is not so simply because the description of the realist, expressionist, and absurdist modes are prototypes which no living play mirrors completely; nor is it so simply because literary history represents a complex process of oscillation and evolution rather than a linear progress. It is problematic first and foremost because all three modes exist quite comfortably side by side in 20th century drama. The constant alternation between - as well as mixture of - realistic and non- 
realistic modes is enough to make both a formalist and a sociological critic feel somewhat at a loss; it certainly makes generalizations about dramatic movements or stylistic periods in modern American drama a precarious matter. O'Neill goes for instance from realism in early plays like Bound East for Cardiff and others, to expressionism in The Emperor Jones (1920), to realism again in plays like Beyond the Horizon (1920) and "Anna Christie" (1921), to expressionism in "The Hairy Ape" (1922), and back to realism somewhat stretched by a few touches of expressionism in All God's Chillun Got Wings and Desire Under the Elms (1924). Then, although moving to a kind of German expressionism in "Marco Millions" (1928), combined with the use of masks in The Great God Brown (1926), Lazarus Laughed (1934), and Days Without End (1934), he uses a mixture of realism and expressionist asides in Strange Interlude (1928), and ends up with dyed-in-the-wool realism in Long Day's Journey Into Night and other late plays. Miller's production is to some extent also a medley of realistic and non-realistic forms: realism in All My Sons (1947), a combination of realism and expressionism in Death of a Salesman (1949), realism in The Crucible (1953), expressionism in After the Fall (1964), and conventional realism again in The Price (1968). Williams's plays reveal a similar vacillation.

Edward Albee's production is, however, perhaps the most extreme formal roller-coaster of all, which is the reason why I will proceed to use his plays as touchstones for illustrations in my subsequent discussion. We have realism in The Zoo Story (1959) and , The Death of Bessie Snith (1960), a mixture of absurdism and expressionism in The Sandbox (1960) and The American Dream (1961), realism in Who's Afraid of Virginia Woolf? (1961), symbolist expressionism in Tiny Alice (1964), realism again in A Delicate Balance (1966), a sort of surrealist expressionism in Box and Quotations from Chairman Mao Tse-Tung (1968), expressionism with some touches of realism in All Over (1970), fabulation in a realistic framework in Seascape (1975), something between absurd and expressionistic drama in Listening (1976), and absurdism in Counting the Ways $(1977) .10$

The enumeration of these different terms seems perhaps a shade ridiculous as they somewhat inadequately try to synthesize the formal heterogeneity typical of many of Albee's plays. There would of course be no need for these terms if Albee's plays, regardless of their mode, could be said to reflect the same general themes. This, however, is not the case unless themes are defined as "motifs" such 
as "loss of love," "materialism vs. humanism," "abrogation of personal responsibility," and the like. If one defines theme in cultural terms as "vision of the world," or in formalist terms as the "core of meaning" which organizes all the features of a work, then Albee's plays must be regarded as having radically different thematic implications, which I will proceed to show in my subsequent analyses.

\section{II}

For reasons of synthesis it may be useful to disregard chronology for a while and examine together those plays by Albee that are formally and thematically closely related to each other. Since Albee started out as a realist playwright, it is perhaps natural to begin with his plays of realism, and then move on to discuss his expressionist and absurdist plays. My inclusion of The Zoo Story among Albee's realist plays breaks, however, with some prevalent views of his first play. In "Albee and the Absurd: The American Dream and The Zoo Story," for instance, Brian Way argues that The Zoo Story partly belongs in the tradition of the theater of the absurd because the action and the dialogue are dislocated and arbitrary, and because it uses the technique of pseudo-crisis (in Jerry's long story about the $\mathrm{dog}) .{ }^{\mathbf{1 1}}$ In my opinion, however, the dialogue has little of the incoherence that characterizes absurdist plays; it simply represents an intense exchange between a man who wants to be left alone and a man who cannot help forcing himself upon him. If both characters were talking polite nonsense, the play might have seemed absurd, but Jerry never gives Peter a chance to hide safely behind his inane, polite phrases of middle class conventionality. Jerry insistently demands response, contact, communication: "every once in a while," says Jerry, "I like to talk to somebody, really talk." Peter's reticence and Jerry's aggressiveness appear perfectly realistic in view of their respective social situations : Peter the upper middle class executive with a wife, two children, two television sets, two cats, and two parakeets; and Jerry the lonely outcast with a small room in a dilapidated building, among other unhappy derelicts of society. The plot is marked by a careful epic development building up to a final crisis: as Jerry tells the story about his landlady and her dog, his language grows steadily more intense and violent, and Peter's responses are increasingly uncomfortable and helpless. 
Jerry's long monologue is a true climax in the play, a desperate cry for a world of meaningful relations: " $[\ldots]$ it's just that if you can't deal with people, you have to make a start somewhere. WITH ANIMALS! [...] Don't you see? A person has to have some way of dealing with SOMETHING." At the same time, Peter is also finally brought out of his complacency, refusing to understand: "I DON'T WANT TO HEAR ANY MORE." Their final fight for the bench may seem absurd, but it is a meaningful absurdity, the kind of childish anger in which a trifle suddenly becomes of fundamental importance. In a very real sense, Peter's fight for his very own every-Sunday-afternoon bench becomes expressive of his urge to have his self-possession inviolate and his middle-class existence boxed off by rights of ownership. Jerry in fact attacks the basic assumption behind his bourgeois prison of a life: 'I'm on your precious bench, and you're never going to have it for yourself again." The social significance of this individual conflict is brought out time and again in the dialogue, testifying to the play's attempt, not simply to present a psychological conflict, but to illuminate and explain it - which makes the play part of the tradition of analytical realism. This is also brought out by the ending when Jerry "impales" himself on the knife, breaking out of "this humiliating excuse for a jail," as he had put it earlier. As Brian Way says, "Jerry spends his dying breath telling us what the play means as explicitly as does Lona Hessel at the end of Pillars $₫$ Society." 12 Way regards this as a regrettable deviation from an absurdist view; I find it a perfectly appropriate ending to a realist play which dramatizes the humanist necessity for, and (however apocalyptically) the potentiality of, communication and community. Peter's pitiful howl as he runs off also seems to suggest that he will never be quite comfortable on his separate little bench any more.

Being imprisoned by social roles is also the central theme of The Death $₫$ Bessie Smith. Its realism is in many ways that of social protest, expressed not least through its typification of the characters: the black Orderly, hard-working and ambitious, anxious to please and afraid to provoke; the Nurse herself, an incarnation of the cult of white Southern womanhood, who takes her sexual and social frustration out on the "white niggers" and her suitor; and the Intern, a Southern liberal unhappy with racial prejudice but too weak to revolt, protecting his indecisiveness with a sense of irony until finally forced into action through the death of Bessie Smith. 
All of them are unhappy about being stuck where they are and long for a better, more satisfying life: "I am sick," says the Nurse, "I am sick of everything in this hot, stupid, fly-ridden world [...] I am tired of my skin ... I WANT OUT!" The very ambiguity of the word "skin" here reflects the way in which personal and racial frustration are seen to be interconnected, crippling and stifling the humanity of the people of the South.

It is, however, the realism of full-length plays like Who's Afraid of Virginia Woolf? and A Delicate Balance which has given Albee the opportunity for a more complete dramatization of his humanist concerns. The main characters in these two plays are deeply individualized, complex, and vividly portrayed. The dialogue reflects a meaningful conflict deeply rooted in their psychological and social predicament. The concern with mimesis, with the illusion of the fourth wall, is consistently pursued throughout. Of course they are modern plays, so the dialogue is not as "logical" as in plays of conventional realism, more filled with indirection and digression; the plot therefore seems less stringent. Yet the action, however obliquely, always leads toward a meaningful crisis.

The problems dramatized are to some extent the same in both plays, involving couples who have grown apart and are conscious of it, who cannot quite ignore the discrepancy between what they wanted their lives to be, and what they have become. Underneath the verbal exhibitionism in both plays there is a deeply serious note, a sense of loss and frustration. The past of the characters is also constantly brought out in order to illuminate their present predicament, very much in the tradition of analytical realism. As the conflict between the characters grows into a crisis, they are inexorably brought to a greater understanding of themselves and their situation.

The crisis in both plays dramatizes in many ways the opposition between illusion and truth, which is so central to plays within the realist tradition. It is of course Martha's brazen act of adultery which finally provokes George out of his passive withdrawal and makes him destroy their game of make-believe. George's act is motivated by revenge, but there is love involved as well:

$M A R T H A$ : Did you ... did you ... have to?

GEORGE (pause): Yes.

$M A R T H A$ : It was ...? You had to?

GEORGE (pause): Yes.

$M A R T H A$ : I don't know. 
GEORGE: It was ... time.

MARTHA : Was it?

GEORGE: Yes.

There is something close to communion here, and something close to an apology touched with understanding and regret. In a paradoxical way, Martha's adultery was prompted by love, too: "II'll make you sorry you made me want to marry you [...] I'll make you sorry you ever let yourself down." Martha could not allow George to rest in resignation and withdrawal, and he would not let her take refuge in the comfort of an empty illusion. If they stand at the end of the play in a cold and frightening void of shattered illusions, it is something, however angrily and reluctantly, they have chosen - a life they have assumed responsibility for.

The realization of loss is central to the crisis of A Delicate Balance as well: as Harry says, "there's ... so much ... over the dam, so many ... disappointments, evasions, I guess, lies maybe ... so much we remember we wanted, once ... so little that we've ... settled for ...' When Agnes in the end forces Tobias to take a stand in a family divided by conflict, he is finally brought face to face with his own spiritual poverty. Yet he insists on the right of Edna and Harry to live with them:

YOU BRING YOUR PLAGUE!

YOU STAY WITH US!

I DON'T WANT YOU HERE!

I DON'T LOVE YOU!

BUT BY GOD ... YOU STAY!!

Edna and Harry of course leave, and the play ends in a very delicate balance indeed, between a realization of the loss of love, and an inahility to restore it. Agnes has the last words in the play, suggesting that "we'll all forget ... quite soon." Many critics take Agnes's statement as the theme of the play; in my opinion, however, the vision of the play centers above all on Tobias's struggle with himself. His anguished insight into his own complicity and his uncompromising understanding of his own predicament are a kind of achievement after all - and a means by which the play, in terms of the action itself, defines its humanist perspective. ${ }^{13}$

Both these plays reflect the emphasis of conventional realism on identity and integrity of character. Their endings, however, may serve to remind us that they are a far cry from the plays of 19 th century critical realism. Although both Ibsen's drama and many 
modern realist plays tend to stress the importance of self-knowledge, there is a difference in the nature of the insight and the action to which it leads. When Nora slams the gate behind her at the end of A Doll's House, we have a feeling that an entire society shakes in its foundations: "I must find out who is right, society or I." The endings of 20th century realist plays tend to be much less conclusive, whether with the three Tyrones, listening helplessly to Mary's rambling reminiscences; or Martha saying "I don't know" to George's hesitant suggestion that their loss of illusion may be better; or poor Tobias's somewhat pathetic "I was honest [...] Wasn't I?" There is a much stronger presence of a collective, public dimension in the plays of critical realism, where the possibilities of personal change seem to have much wider social implications. This may, of course, be explained historically: the conflict between humanist ideals and social practice was felt to be genuinely alive and acute in the Europe of the 19th century; in the 20th century, however, the implications of the knowledge of self and society are more privatized, more limited by the widening gap precisely between the insight of the individual and the values of his society.

If this gap is experienced as too wide, any insight of the individual may appear so personal, so unrelated to the context of human interaction that dialogue is in danger of becoming a matter of disjointed, subjective statements. It is actually this state of affairs which Albee to some extent dramatizes in expressionist plays like All Over, Tiny Alice, and Listening. In All Over, however, a certain sense of realism is retained through characterization and setting. There is nothing symbolic about the stage set, and the identity of the characters is clearly defined: the self-pity, self-contempt, and immature resentment of the Daughter; the flabby anaemia of the Son; and the anguish of loss in the Wife and the Mistress as they try to hold on to the memory of love and compassion. On the other Band, there is next to no explanation in the play of what has made the characters feel and act as they do: the play resembles the kind of modern drama which according to Arthur Miller merely tries "to show the present countenance rather than to account for what happens." 14 Very little indeed happens in the play: the dialogue wanders back and forth, almost at random; thoughts are broken off and then picked up again like motifs in a musical piece as the characters pursue their own preoccupations. In a way the dialogue constantly threatens to break down into monologues. Thus the play 
may be said to reflect the kind of dramatic "super-naturalism" that O'Neill called for in his programmatic essay "Strindberg and Our Theatre" - a theater which expresses "what we comprehend intuitively of that self-defeating self-obsession which is the discount we moderns have to pay for the loan of life." ${ }^{15}$ In a very real sense the Wife expresses the central vision of the play when she says at the very end: "All we've done is think about ourselves. Ultimately." At the heart of the play is a fundamental contradiction: the characters (the Wife and the Mistress in particular) talk about love and kindness, but are unable to practice either; they talk about understanding, but it does not lead anywhere except back into their own sense of emotional deprivation and loneliness. "I don't love anyone," says the Wife - love is all over. This may remind us of the final situation in $A$ Delicate Balance, but only in a superficial sense: in A Delicate Balance, there is a sense of process and development, of human interaction and communication; in All Over, conflicts are little more than emotional masturbation as each and all are imprisoned within their own selves. All Over is in a sense a play in which thematic motifs of realist drama beat helplessly, in an anachronistic fashion, against an expressionist form and vision of the world.

To use the term "expressionist" about a play like All Over may seem somewhat eccentric; the lack of any symbolic projection through the stage set makes one tempted to coin some alternative term like "modernist play." There is a curious kind of objectivity about the play as well; the dramatist seems to stand aloof from the characters. In Tiny Alice, however, the stage set clearly functions in symbolic manner, and the play presents a subjective vision very much in the tradition of expressionist drama. It is, quite simply, Julian's play; its focus of identification is first and foremost on his search for a faith. The symbolic function of the castle within the the castle destroys the impression of verisimilitude; any sense of realism is furthermore undermined as the play assumes the character of an ironic and ominous game. The play bears a resemblance to Strindberg's dream plays, in which reality has somehow turned into a nightmare, plotted by mysterious forces of fate for metaphysical ends which are hidden from the main character as well as the audience. The play is thus deeply meaningful, but its dreamlike quality makes it strangely allusive. As Julian unwittingly enters the plot, the dialogue becomes extremely equivocal and opaque. Julian's predicament may perhaps function as a symbolic illus- 
tration of the way in which modern man feels thrown willy-nilly into the world, trying helplessly to make sense of it for himself. The ending, however, is ambiguous: it is not clear whether Julian, who was deeply "dedicated to the reality of things, rather than their appearance," ends up embracing an illusion or an essential reality. This fundamental uncertainty is reflected in Albee's own comments on the play at his press conference:

He is left with pure abstraction - whatever it be called: God or Alice - and in the end, according to your faith, one of two things happens. Either the abstraction personifies itself, is proved real; or the dying man, in the last necessary efforts of self-delusion, creates and believes in what he knows does not exist. ${ }^{16}$

One may see this central ambiguity as the result of the deeply symbolic form and subjective perspective of the play: the lack of references to an objective reality renders any definite sense of knowledge difficult.

In Listening, the note of uncertainty is much stronger because it depicts a more pervasive relativity in human relations. This impression is engendered by the many features of absurdist drama in this play: the dialogue which frequently dissolves into disconnected and meaningsless exchanges of phrases; the characters who switch roles, being alternately master and underdog; the Woman and the Girl who fail to remember scenes of the past; the Girl who snaps to attention like a mechanical doll; and the many repetitions of the theme of meaninglessness and futility: "It's reasonable [...] Nothing is reasonable;" "Who's nice? Who's anything?" Yet these traits of absurdism are only there as motifs; the play as a whole deals with the predicament of these characters in a symbolist fashion. It is significantly entitled "A Chamber Play," in which the motives of listening or not listening appear in constantly changing contexts throughout the play, making it reminiscent of the kind of wandering dialogue whose material according to Strindberg is "worked over, picked up, repeated, developed, expounded, like the theme in a musical composition." The suggestive, symbolic stage set is no less Strindbergian: the meeting place with the semi-circular wall, the empty fountain pool, and the monster head. This setting somehow seems to suggest a lost order: "Back when all this ... overgrowth was a formal garden - clipped and trained and planned and ... then it was full, I imagine [...] Back when all this was ... back before it had all become ... impersonal?" The monster head itself may be an embodiment of the inhumanity 
and cruelty which are the characters' present response to each other, to an environment which has become loveless and sterile. The play is more complex than that, however, since the characters sometimes do pay attention to each other, and insist that they do understand, although they are always automatically contradicted. This raises the question whether each character's sense of isolation reflects a universal condition humaine or whether it actually springs from a personal failure to take responsibility for love and compassion. This ambiguity is left unresolved even in the ending, when the girl has cut both her wrists:

\section{THE GIRL (Pause)Then ... you don't listen. \\ THE WOMAN (Longpause) I listen. \\ THE VOICE (Long pause) End.}

The difference between Listening and a play like Counting the Ways is perhaps one of degree rather than kind. The features of absurdism seem, however, to dominate the latter play to a much greater extent: neither HE nor SHE has much individuality; the mimetic wall is not only broken by signs being lowered from above, but also by the actors adressing the audience or talking about themselves as actors; and the dialogue is more glaringly incoherent and seems to lead nowhere. Lack of communication is reflected by the way in which they exchange quite unrelated observations and thoughts, and by the way in which they jumble together serious and trite subjects. The play is significantly subtitled "A Vaudeville," which calls to mind the musical hall comedy of the theater of the absurd. The ending, however, shifts the mechanical-habitual do-you-loveme questions and answers to an entirely different level:

HE (Closing the subject) I do ... love you.

(Long pause; a half-amused afterthought)

Do you love me?

SHE (Pause; very open, rather wistful)

I don't know.

(Pause; his mouth opens a little. SHE speaks as gently as the subject will allow;

SHE smiles to reassure him)

SHE (Continued) I think I do.

(Pause. Slow fade)

END

Here is a sudden revelation, a shock of honesty combined with gentleness, which breaks completely with the absurdist mood. This is symptomatic of a kind of plot which is more consistently and significantly pursued in The Sandbox and especially The American 
Dream: they do not have the repetitive or circular structure of absurd drama but a genuine development which leads to a climax at the end of the play. Thus, formally, plays like The Sandbox and The American Dream cannot really be said to be absurdist; rather, they combine absurdist features with a form which for want of a better term can be said to be expressionistic.

The elements of absurdism in The American Dream are above all found in the exchanges of platitudes and clichés between the characters, and the way in which polite phrases are jumbled together in an inane chatter, testifying to the deterioration of language and the breakdown of communication. The impression of senselessness is deepened as characters sometimes forget what was just said, or fail to remember what they should be doing, and why. The comic absurdity of the action reaches a high point when Daddy looks for Grandma's television and blind Pekinese and finally her room, unable to find any of these things because Grandma has hidden everything. Seen in isolation, these features are purely absurd, but in the play they function within a specific social context, which makes them part of a meaningful rather than a meaningsless world view. There is an element of direct social caricature in both characterization and dialogue which has often been overlooked in this play. It reveals how human relationships in general and marriage in particular have become a matter of materialistic consiclerations; how the relations between the sexes have been reduced to masculine and feminine stereotypes; how family cohesion has disappeared and old people are written off. The most explicit social criticism is of course embodied in the figure of the Young Man himself, the goodlooking American Dream who has been "drained, torn asunder ... disemboweled" and left emotionally sterile, doing "almost anything for money." Throughout The American Dream, Albee dramatizes the destruction of human empathy and understanding through specific social attitudes that are savage and dehumanizing.

Thus, if life seems meaningless in this play, it is because of personal and social failure, and not because man inhabits a senseless universe: the absurdity is social, not universal. This becomes evident not least through the characterization of Grandma, who in both The Sandbox and The American Dream is a curiously positive character. She is the only person who can stand up to Mommy, she has a sense of humor and detachment, and her statements put the rest of the dialogue in its proper, sterile perspective. The 
ending of The American Dream is particularly interesting in this connection,' as Grandma stands watching the scene and turns directly to the audience: "Well, I guess that just about wraps it up. I mean, for better or worse, this is a comedy [...] let's leave things as they are right now ... while everybody's happy ... while everybody's got what he wants ... or everybody's got what he thinks he wants. Good night, dears." Thus Grandma, functioning as a sort of deus ex machina to see that everyone gets what he deserves, ends up as a sort of expressionist narrator standing apart from the inanities of the other characters. Their illusions are not hers; she becomes somebody, however imperfect, against whom the other characters are judged and found wanting.

Grandma, however, is seen to be moving away into death, and the characters who remain leave little hope for humanity. The humanist perspective of the play, excepting Grandma, is not in the world of the drama, but of its form. This is also true of Box and Quotations from Mao Tse-Tung, whose contrapuntal musical structure expresses the central concerns of the play. The use of setting and characters is quite surrealistic: the deck of an ocean liner within the outlines of a cubic box, where we find Chairman Mao, an upper-middle class Long-winded Lady, a poor Old Woman, a Minister who never says a word, and finally the Voice of the Box. There is no real dialogue between them; they all seem, as Albee says in his stage directions, primarily "interested in what they themselves are doing and saying." What the play lacks in terms of conflict, however, it gains in the imaginative contrasts between what is essentially three separate monologues. The most striking contrast is that between Mao's declarations of total dedication and conviction and the Long-winded Lady's reflections of uncertainty and passive resignation. The absolute and general character of Mao's assertions generates, however, a somewhat cold and impersonal tone when played off against the individual anguish of the Long-winded Lady's introverted thoughts and reminiscences. Finally, of course, none of the participants in this quorum prevails over the others; the main impression is one of lack of communication. The Voice from that cube, like all of them separately squared off, has the final say: "Nothing belongs."

The essential difference in world view between Albee's realist plays and the kind of drama represented by Box and Quotations from Mao Tse-Tung is very poignantly brought out by the Voice from the Box: 
When art begins to hurt ... when art begins to hurt, it's time to look around. Yes it is.

\section{(Three-second silence.)}

Yes it is.

(Three-second silence.)

No longer just great beauty which takes you more to everything, but a reminder! And not of what can ... but what has. Yes, when art hurts ...

- -

When the beauty of it reminds us of loss. Instead of the attainable. When it tells us what we cannot have ... well, then ... it no longer relates ... does it.

- - -

When art hurts. That is what to remember.

(Two-second silence.)

What to look for. Then the corruption ...

(Three-second silence.)

Then the corruption is complete.

Albee's realist plays, above all Who's Afraid of Virginia Woolf? and A Delicate Balance, represent in a sense an art which "takes you more to everything": they affirm the authentic potentiality of humanism through their dialogue, characterization, and plot. The values of understanding oneself and others, and of assuming personal responsibility for one's life, are realized through interaction and communication within the worlds of the plays themselves. Thus Albee's realism serves to remind us not simply of what we cannot have; it reminds us also of what we may - and should try to - attain.

The expressionistic, highly symbolic form of plays like Tiny Alice and Listening, however, reflects the decline of the public perspective of social interaction. "Character identity" has become more uncertain and ambiguous, and the dialogue has grown more subjective, fragmented, and opaque. The lack of an "objective" or "ordinary" reality marks perhaps not so much the absence of a humanist dimension as the privatization of humanism. As I suggested in my analysis of these plays, the sense of uncertainty that pervades these plays may be a result of their exclusory concern with subjective experience. Their fundamental ambiguity can perhaps be regarded as the dramatic equivalent of the kind of ambiguity which often characterizes modernist poetry and fiction.

Expressionist-absurdist plays like The American Dream and Box and Quotations from Mao Tse-Tung, however, dramatize a world totally devoid of humanist values. Their "practice" is one of isolation and lovelessness; values of human interdependence remain "theoretical" - they are a matter of formal projection and impli- 
cation, serving as "a reminder" of what has been lost. The Voice from the Box characterizes this kind of drama very well: when art "tells us what we cannot have," then it "no longer relates" to a humanist conception of the world: the "corruption" of society and the individual "is complete".

\section{III}

It is in my opinion both puzzling and remarkable that a dramatist can, as Albee does, constantly vacillate between such radically divergent visions of human existence. As I have pointed out earlier, Albee is certainly not unique in this respect; both O'Neill and Miller, for instance, also use different dramatic modes. In the case of these latter playwrights, however, a conventional historicalsociological point of view brings us at least part-way towards an explanation. O'Neill's expressionist plays of the mid and late $20 \mathrm{~s}$ can be said to reflect the deep alienation from the American mass production and mass consumption society that emerged after the war. Likewise his return to realism in the late 30 s and early 40 s can be explained in terms of the objective-mimetic perspective that followed in the wake of the Great Depression. This had a lasting impact on the 40s and 50s as well; Miller's preference for the mode of social realism can certainly be regarded as a result of the renewed interest in describing man in relation to his social context. Nevertheless the problems of formal vacillation inherent in Albee's production are to be found with O'Neill and Miller as well: realist and expressionist modes are used almost alternately in $\mathrm{O}^{\prime} \mathrm{Neill}$ 's plays from the early 20s, and Miller moves for instance directly from an expressionist form in After the Fall (1964) to conventional social realism in The Price (1968).

The inadequacy of a period-type approach in this connection makes one tempted to seek the cause of such formal vacillation elsewhere, for instance in the author's biography or in the choice of the subject matter for individual plays. It is difficult, however, to see exactly how changes in a dramatist's personal convictions could serve as explanation: vacillation is something quite different from development. And, although O'Neill (like Strindberg) went through different stages in which he turned to radicalism, anarchism, mythology, and conservatism, Albee's and Miller's lives seem to reflect no such extreme ideological fluctuations. 
The dramatists themselves seem to consider the nature of the subject matter important for their choice of dramatic mode. As O'Neill puts it in an interview in 1922, "I intend to use whatever I can make my own, to write about anything under the sun in any manner that fits or can be invented to fit the subject.' 17 But it becomes very difficult to see precisely what kind of subjects appeals to one rather than another mode of drama. Miller, however, presents a definite theory as to the nature of the topics that may tend to influence the use of specific modes:

I have come to wonder whether the force or pressure that makes for Realism, that even requires it, is the magnetic force of the family relationship within the play, and the pressure which evokes in a genuine, unforced way the un-realistic modes is the social relationship within the play [...] so long as the family and family relations are at the center of his [O'Neill's] plays his form remains indeed, it is held prisoner by - Realism. When, however, as for instance in The Firy Ape and Emperor Jones, he deals with men out in society, away from the family context, his forms become alien to Realism, more openly and selfconsciously symbolic, poetic, and finally heroic. ${ }^{18}$

It is possible that this theory is of some relevance, since family relationships are in themselves usually perceived as individualistic and therefore may produce a stress on verisimilitude, whereas social relationships may be felt and perceived as more abstract and thus call for a more symbolic presentation. The central feature of realism, however, is - as Miller himself has pointed out in his "Introduction" to Collected Plays - that it tends to emphasize both man's individual and social relations, and that indeed the family is seen as a mirror of the social, context. What is more, Miller's own examples do not really hold water if analyzed more closely. It is the social aspect of The Emperor Jones which is described in such vividly realistic terms in the first scene, and the wilderness of his own mind which is brought out in expressionist terms. When we study a play like Miller's own Death of a Salesman, for instance, which is a combination of the realistic and expressionistic modes, we discover that realism is not used especially for presenting the familial relationships or expressionism especially for the social ones - both modes are used in both instances. And a highly expressionistic play like O'Nieill's The Great God Brown, for instance, deals not least with family relations. In my opinion, it is in the final analysis not primarily the subject matter which determines the choice of mode, but rather the fundamental thematic implications of the work - its world view. 
Since the world view of a dramatist's work is determined primarily by his reaction to his own society, we are back with an historical-sociological explanation. Maybe such an explanation can best account for vacillation in dramatic form if it is combined with, and qualified by, intrinsic considerations. An important factor to take into account is the stylistic restlessness inherent in the act of writing itself. As Albee says in his "Introduction" to Box and Quotations, "since art must move, or wither - the playwright must try to alter the forms within which his precursors have had to work." One may suggest that American dramatists in general seem to have constantly felt the need to experiment with different ${ }^{c c}$ European" forms - expressionism and absurdism in particular without being able to feel quite at home with them: hence their vacillation. Major American playwrights seem caught in a dilemma which is described in an interesting way by Miller:

Why, if Ibsen and several other playwrights could use Realism so well to make plays about modern life, and if in addition the modern American audience is so quickly at home with the form - why should playwrights over the past thirty years be so impatient with it? Why has it been assaulted from every side? Why do so many people turn their backs on it and revere instead any kind of play which is fanciful or poetic? At the same time, why does Realism always seem to be drawing us all back to its arms? We have not yet created in this country a succinct form to take its place. ${ }^{19}$

Whether one regards this formal instability as an inability to remain within a realist vision, or as an inability to feel at home with non-realist forms, it seems natural to attribute it to the nature of modern American society. At least this is what playwrights and critics sometimes do, especially when they discuss why the theater of the absurd never seems to have made the same impact in America as in Europe. Albee says for instance that "it is my guess that the theatre in the United States will always hew more closely to the post-Ibsen/Chekrov tradition than does the theatre in France, let us say. It is our nature as a country, a society." ${ }^{20}$ Martin Esslin uses a similar argument when he tries to explain the "dearth of examples of the Theatre of the Absurd in the United States": "the convention of the Absurd springs from a feeling of deep disillusionment, the draining away of the sense of meaning and purpose in life, which has been characteristic of countries like France and Britain in the years after the Second World War. In the United States there has been no corresponding loss of meaning and pur- 
pose." 21 There is a good deal of truth in these statements, as one can see when comparing the radical literary tradition in modern France with the tradition of liberalism among playwrights in America. Yet such a general theory encounters some rough waters when we consider the literary experimentation in the American 1960s. Although absurd drama did not break through in America with the same force as in France or Britain, absurdism made a considerable impact on the novel with the so-called fiction of fabulation or irrealism. Are we, then, going to make a sociological distinction between drama and fiction in the United States?

This distinction may be both tenable and important. A large, variegated readership seems to make novelists more able than dramatists to pursue their own formal preferences, whether this takes them predominantly in the direction of realism (as with Bellow or Malamud), or predominantly in the direction of fabulation (as with Barth or Barthelme). The process of getting produced on stage for a large audience poses, however, particular problems for the dramatist, especially in the United States. Thus the theater as a sociological institution in America may make drama less "free" than fiction, and consequently more unstable. As Edward Albee suggests in his essay "Which Thetre Is the Absurd One?", boxoffice considerations - what the producer thinks the public wants appear to be more decisive in the United States than in Europe. ${ }^{22}$ True avant-garde drama has great difficulties in gaining recognition from the Establishment; it is often fated to remain off Broadway or even off-off Broadway. Although I certainly do not suggest that established dramatists in America write for profit, the demands of the institution of the theater itself may be one of several reasons for the formal instability in American drama.

Although realist and non-realist modes exist side by side in modern European drama as well, extreme vacillation in dramatic form within the productions of individual playwrights appears to be particularly an American phenomenon. Thus it seems possible to argue that the character of American culture and the nature of the American theater serve to make formal instability at least more pervasive in the United States than elsewhere. A more general explanation for such instability may on the other hand be that the society of the 20th century - especially since World War II encourages a variety of radically different responses at one and the same time. In extreme cases, as with Albee, it may be the particular mood of the dramatist at a given moment which somehow deter- 
mines his vision of the world, and hence his form. Thus some dramatists may feel that the three major dramatic modes - realism, expressionism, and absurdism - each expresses important, and equally relevant, aspects of modern life. Certainly the coexistence and combination of these three modes in contemporary drama can be seen to testify - more than any one of them individually - to the disharmony, not to say schizophrenia, of contemporary life.

\section{NOTES}

1 Harper's Magazine, 217 (August 1958), 39.

2 I am here concerned with the strain of expressionism that has evolved from Strindberg's plays, where the characters, although fragmented, are individualized at the same time. In the so-called German expressionism, on the other hand, ideas rather than individuals tend to be dramatized: characters often function primarily as types, as mouthpieces for social or psychological attitudes.

3 In August Strindberg, Fadren/Fröken Julie (Stockholm: Aldus/Bonniers, 1961), p. 63. Several English translations have been checked against the original.

4 Ibid., p. 66.

5 The Theatre of the Absurd (Harmondsworth: Penguin, 1968), p. 396.

6 "Introduction" to his Collected Plays (New York: Viking, 1957), p. 19.

7 In August Strindberg, Till Damaskus-I/Ett drömspel (Stockholm: Aldus/ Bonniers, 1962), p. 80. Several English translations have been checked against the original and somewhat modified.

8 The Making of Modern Drama (New York: Farrar, Straus and Giroux, 1974), p. 107.

9 The Theatre of the Absurd, p. 265. The comment appears in his discussion of Pinter's plays.

10 I have omitted Albee's dramatic adaptions from my discussion, partly for reasons of space, and partly because adaptions involve additional problems not within the scope of this paper to discuss.

11 See Brian Way, "Albee and the Absurd: The American Dream and The Zoo Story," in G. W. E. Bigsby, ed., Edward Albee: A Collection of Critical Essays (Englewood Cliffs, N. J.: Prentice-Hall, 1975), especially pp. 37-41.

12 Ibid., p. 41.

13 I have omitted Seascape from this discussion of Albee's realist plays. Seascape turns of course into a phantasy piece when Leslie and Sarah make their entrance on stage with their green lizzard tails, but the dialogue, plot, and theme of the play are largely within the convention of realism. The central idea of the play becomes all too clear at the end: as Leslie and Sarah must and should evolve, so must Charlie and Nancy as well in order to attain a more meaningful life together. Although the play is full of surprises and a good deal of fine humor, I have excluded it because it in my opinion represents too facile a treatment of a motif which is presented with far more depth and compiexity in Who's Afraid of Virginia Woolf? and A Delicate Balance.

14 "Introduction" to his Collected Plays, p. 21.

15 In Oscar Cargill et al., eds., O'Neill and His Plays: Four Decades of Criticism (New York: New York Univ. Press, 1961), p. 108.

16 Quoted in Ronald Hayman, Edward Albee (London: Heinemann, 1971), p. 62. 
17 Quoted in Egil Törnqvist, A Drama of Souls: Studies in Eugene O'Neill's Supernaturalistic Technique (New Haven: Yale Univ. Press, 1969), p. 28.

18 "The Family in Modern Drama," Atlantic Monthly, 197 (April 1956), 36.

19 Ibid., 36. It is indeed quite possible to argue that the best American drama has either been that of realism proper (as in Long Day's Journey Into Night, The Iceman Cometh, The Crucible, and Who's Afraid of Virginia Woolf?'), or that of a combination of realist and non-realist forms (as in Death of a Salesman, The Glass Menagerie, and A Streetcar Named Desire). Even plays that seem more definitely slanted towards expressionism, like The Emperor Jones, The Hairy Ape, and The American Dream, have a strong strain of realism, a solid edge of reality which modifies and concretizes the symbolic vision.

20 "Which Theatre Is the Absurd One?" in Walter J. Meserve, ed., Discussions of American Drama (Boston: D. C. Heath, 1965), p. 150.

21 The Theatre of the Absurd, p. 301.

22 See pp. 146, 148-149. 